\title{
PEMIKIRAN DAN PRAKSIS DAKWAH SUFISTIK M. FETHULLAH GÜLEN
}

\author{
Sokhi Huda \\ Universitas Hasyim Asy'ari Tebuireng Jombang, Indonesia \\ E-mail: sokhi.huda@yahoo.co.id
}

\begin{abstract}
This article discusses a study of the existence of Sufism of the contemporary Islamic preaching of $\mathrm{M}$. Fethullah Gülen. The thought of Gülen's Islamic preaching originates from his view of Sufism as the spiritual life and the journey of a human life to achieve happiness in this world and hereafter. This thinking evolves and can be accepted by the global community in the contemporary era. This thought disseminates the ideas of love, tolerance, and pluralism and receives attention from over 160 countries. Then, the praxis of the Gülen's Islamic sufi preaching manifestes into Islamic preaching practices with a methodical system that emphasizes the hizmet movement with the philanthropist and contemporary media tactics. This praxis exists in its role of producing the golden generation progressively, contributing to an increase in the positive image of Islam and Muslims and moral development of the world community.
\end{abstract}

Keywords: Islamic sufistic preaching; Gülen movement.

\section{Pendahuluan}

Dakwah pada era kontemporer menghadapi tantangan baru searah dengan kecenderungan arus zaman. Pelbagai pendekatan yang sudah mapan atau dianggap mapan pada dekade sebelumnya ${ }^{1}$ memerlukan koreksi dan revisi di era ini. Era kontemporer yang diwarnai oleh kemajuan yang pesat, utamanya bidang teknologi informasi, turut memacu akselerasi dalam transformasi budaya, ideologi, dan

\footnotetext{
${ }^{1}$ Lihat, sebagai konfirmasi, pada Moh. Ali Aziz, Ilmu Dakwah (Jakarta: Kencana, Edisi Revisi ke-3, 2012), 345-349; Muhammad Abû al-Fatḥ al-Bayânûnî, al-Madkhal ilâ Ilm al-Da'wah (Beirut: Muassasat al-Risâlah, 1993), 195-198. Rabî‘ b. Hâdî alMadkhalî, Manhaj al-Anbiyâ' fì al-Da'wah ilâ Allâh fì al-Hikmab wa al-'Aql (Kuwait: Dâr alSalafiyah, 1987); 'Alî 'Abd Halîm Mahmûd, Fiqh al-Da'wah al-Fardîyah (Mesir: Dâr alWafâ, 1992); A. Ezzati, The Spread of Islam: Contrbuting Factors (Willesden, London: Islamic College for Advanceed Studies Press/ICAS, 2002).
} 
perkembangan ilmu pengetahuan. Oleh karenanya pada realitasobjektif, dakwah tertuntut untuk merespons kecenderungan era kontemporer tersebut dengan mengakselerasi pendekatan-pendekatan yang efektif dan produktif, sama halnya pada metode-metode dan teknik-tekniknya. Tuntutan ini lebih karena pertimbangan, dakwah sebagai ujung tombak penyebaran nilai-nilai Islam ke seluruh penjuru dunia harus senafas dengan zaman agar tidak kehilangan roh relevansifaktualnya. Ikhtiar semacam ini dapat ditemukan pada sosok pemikir Turki kontemporer, M. Fethullah Gülen melalui pemikiran dan aksi dakwahnya.

Gülen adalah seorang tokoh besar Islam kontemporer berkebangsaan Turki yang beraliran Sunnî-Hanafî dengan pengaruh utama pemikiran Saî̀d Nursî (1878-1960). Perhatian utamanya adalah pemikiran Islam ortodoks, konservatisme Islam, pendidikan, dialog antar-agama dan budaya, dan menjadikan tasawuf sebagai spirit sentralnya. ${ }^{2}$ Spirit inilah yang menjadi motor utama gerakan dakwah Gülen ke berbagai penjuru dunia melalui gerakan yang akrab disebut birmet. Seleksi sejarah mengantarkannya menjadi tokoh paling populer setelah dianugerahi sebagai tokoh intelektual nomor wahid di dunia, menang telak atas 99 tokoh lainnya dari 100 tokoh intelektual, dengan perolehan lebih dari 500.000 suara masyarakat global menurut versi survei majalah The Guardian, 23 Juni $2008 .^{3}$

Kekhasan pemikiran dan popularitas Gülen menarik untuk ditelusuri lebih jauh tentang biografi, sumber-sumber pemikiran, teologi, proyek utama, inspirasi dan daya kembang gerakan, serta pengaruh dan kontribusinya untuk Turki sendiri, Islam, dan masyarakat global, khususnya yang terkait dengan spirit dakwahnya. Paling tidak ada empat problem akademis yang diajukan dalam telaah ini, yaitu: a) idealisme dan tantangan dakwah kontemporer; b) problem

2 Pim Valkenberg, Renewing Islam by Service: A Christian Wiew of Faetbullah Gülen and Hizmet Movement (Washington, D.C.: The Catholic University of America Press, 2015), 131; Anas et.al., "Fethullah Gülen Movement in South Asia," Indian Council of World Affairs Issue Brief, 5 October 2016, 1; Greg Barton, "Preaching by Example and Learning for Life: Understanding the Gülen Hizmet in the Global Context of Religious Philanthropy and Civil Religion," dalam Ihsan Yilmaz (ed.), Muslim World in Transition: Contributions of the Gülen Movement (International Gülen Conference Proceedings), London, United Kingdom, 25-27 October 2007 (London: Leed Metropolitan University Press, 2007), 654.

3 Daniel W. Skubik, "Fethullah Gülen, Islamic Banking and Global Finance," A Paper Prepared for the Fourth Conference on International Corporate Responsibility, Doha, Qatar, 16-18 November 2008, 1. 
maraknya fundamentalisme di dunia Islam, termasuk di Barat; c) perilaku formalistik keberagamaan; dan d) problem historis kultural dalam relasi global yang hendak dijawab melalui tulisan ini.

\section{Pemikiran Dakwah Sufistik M. Fethullah Gülen}

Dalam pemikiran M. Fethullah Gülen, sufisme merupakan spirit mendasar yang menjadi landasan semua konsep pemikirannya. Konsep-konsep ini merupakan ekspresi dari usaha pencerahan yang dilakukan oleh Gülen, sedangkan dakwah merupakan konsekuensi wujud langsung dari pencerahan ini. Bentuk dakwah ini adalah biæmet yang mengutamakan keteladanan (uswab). Pemikiran dakwah sufistik Gülen ini dapat ditelusuri sumbernya dari buku-buku yang ia tulis: Criteria or the Light of the Way, Pearls of Wisdom, Toward a Global Civilization of Love and Tolerance, The Necessity of Interfaith Dialogue: A Muslim Perspective.

Penulis menemukan kran pembuka pemikiran Gülen tentang dakwah sufistik dari pandangannya, sufism is the spiritual life of Islam. Those who represent Islam according to the way of the Prophet and his Companions have never stepped outside this line. A tariqah is an institution that reaches the essence of religion within the framework of Sufism and by gaining God's approval, thus enabling people to achieve happiness both in this world and in the next. ${ }^{4}$ Pandangan Gülen ini bermuatan worldview tentang sufisme yang merupakan cara hidup Nabi dan para sahabatnya. Cara hidup ini merupakan suatu kemestian untuk diikuti oleh siapapun yang merepresentasi Islam. Ungkapan a tariqah is an institution..., thus enabling people to achieve happiness both in this world and in the next mengarah pada ungkapan cara hidup tersebut ke wilayah dakwah yang bertugas mereformasi hidup masyarakat agar mereka mencapai kebahagiaan di dunia dan akhirat. Hal ini dilengkapi Gülen dengan penyediaan konsep praktis sufisme dalam bukunya yang paling sistematis Key Concept in Practice of Sufism: Essentials of the Islamic Faith. ${ }^{5}$

Kran pembuka ini penulis lanjutkan ke penelusuran terhadap karya-karya Gülen untuk memperoleh deskripsi yang sistematis tentang dakwah sufistik dalam pemikiran Gülen. Pos-pos utamanya dapat dideskripsikan sebagai berikut:

${ }^{4}$ M. Fethullah Gülen, Toward a Global Civilization of Love and Tolerance (New Jersey: The Light Inc. \& Isik Yayinlari, 2004), 166.

${ }^{5}$ M. Fethullah Gülen, Key Concepts in the Practice of Sufism: Emerald Hills of the Heart, Vol. 1-4 (New Jersey: the Light Inc.; Tughra Books: 2004, 2009, 2011). 
1. Gülen menetapkan paradigma idealitas dakwahnya, yaitu rahmat bagi seluruh alam semesta. Idealitas ini dapat ditemui dalam karyanya Islâm raḥmat li al-'álamin. ${ }^{6}$

2. Paradigma tersebut berbasis idealitas rahmat Islam dari al-Qur'ân dan sunnah Nabi. Basis idealitas dari al-Qur'ân secara ekspresif dapat ditemukan dalam karya-karya Gülen, di antaranya adalah: Reflections on the Qur'an'; Windows onto the Faith, Volume 5 (the Qur'an: the Final Revelation). ${ }^{8}$ Al-Qur'ân juga tampak kuat sebagai basis normatif dan argumen logis pada saat Gülen menjelaskan urgensi dan kerangka kerja dialog antariman dan antarbudaya dalam bukunya The Necessity of Interfaith Dialogue: A Muslim Perspective. Selanjutnya basis idealitas rahmat Islam dari Sunnah Nabi dapat ditemukan dari karya-karya Gülen, Sirah Nabawiyah. ${ }^{10}$

3. Gülen menetapkan pendekatan utama dakwahnya pada dimensi sufistik dengan pengutamaan pada aspek cinta dan toleransi, sebagaimana dijelaskan dalam bukunya Toward a Global Civilization of Love and Tolerance.

4. Gülen menetapkan pendekatan utama tersebut berada dalam kerangka tindakan, yaitu dakwah sebagai jalan terbaik bagi pemikiran dan sikap hidup. ${ }^{11}$ Kerangka tindakan ini merupakan sebuah desain dakwah Gülen seperti blueprint bagi sebuah bangunan intelektualisme. Kerangka ini terbaca oleh pandangan para ilmuwan terhadap ajaran-ajaran Gülen, di antaranya adalah ajarannya

${ }^{6}$ M. Fethullah Gülen, Islam Rahmatan Lil-'Alamin, terj. Fauzi A. Bahreisyi (Jakarta: Republika, 2013).

${ }^{7}$ M. Fethullah Gülen, Reflections on the Qur'an (New Jersey: the Light Inc., 2006); M. Fethullah Gülen, Cahaya al-Qur'an bagi Selurub Makbluk (Jakarta: Republika, 2011).

${ }^{8}$ M. Fethullah Gülen, Windows onto the Faith, Vol. 5 (the Qur'an: the Final Revelation) (Somerset, New Jersey: The Light, Inc., 2005).

${ }_{9}$ M. Fethullah Gülen, Windows onto the Faith, Vol. 10 (The Necessity of Interfaith Dialogue: A Muslim Perspective) (New Jersey: The Light Inc., 2005). Bentuk artikel dari buku ini dapat ditemui di situs resmi fGülen.com dan majalah The Fountain, Issue 31/July-September 2000 pada URL: http://www.fountainmagazine.com/Issue/detail/The--NecessityOf-Interfaith-Dialogue.

10 M. Fethullah Gülen, Prophet Mubammad the Infinite Light, Vol. 1 (London: Truestar, 1996), M. Fethullah Gülen, Prophet Muhammad the Infinite Light, Vol. 2 (Istanbul: Kaynak, 1998); Prophet Muhammad: Aspects of His Life, Vol. 1 dan 2 (Fairfax: the Fountain, 2000); M. Fethullah Gülen, Mubammad the Messenger of God: an Analysis of the Prophet's Life (New Jersey: the Light, Inc. dan Isik Yayinlari, 2006).

11 Gülen, Dakwah: Jalan Terbaik dalam Berfikir dan Menyikapi Hidup, terj. Ibnu Ibrahim Ba'adillah (Jakarta: Republika Penerbit. 2011). 
bahwa, komunitas Muslim memiliki tugas pelayanan ${ }^{12}$ dengan "kebaikan bersama" dari masyarakat dan bangsa ${ }^{13}$ serta Muslim dan non-Muslim di seluruh dunia. ${ }^{14}$

5. Gülen menyiapkan ragam perangkat pencerahan dan solusi yang meliputi: a) nilai-nilai spirit berbuat kebajikan ${ }^{15}$ (pencerahan dan solusi normatif); b) tindakan membangun dunia ${ }^{16}$ (pencerahan dan solusi praksis); dan c) upaya membangun kesiapan psikis untuk dinamika hidup di ruang publik ${ }^{17}$ (pencerahan dan solusi psikologis).

6. Gülen menyediakan konsep golden generation (generasi emas) dengan proyeksi terciptanya ideal buman (manusia ideal) dan ideal people (individu paripurna). ${ }^{18}$ Proyeksi ini ditempatkan dalam kerangka visi Gülen berwujud the New Age of Faith and Moral Values.

7. Pemikiran dakwah sufistik Gülen diarahkan pada pencapaian tujuan berupa kondisi ideal, the Golden Era (Age of Happiness). ${ }^{19}$ Kondisi ini, dalam terminologi historis versi penulis, dapat disebut New Color of the Contemporary History: A Reliable Association of the Global Society and Civilization.

Berdasarkan data-data yang ada, dapat dipaparkan lima poin eksistensi pemikiran dakwah sufistik Gülen sebagai berikut.

1. Aktualisasi Pemikiran dalam Kesatuannya dengan Praktik

Gülen mengaktualisasikan pemikiran dalam kesatuannya dengan praktik, sehingga pemikiran tersebut tidak hanya bergerak pada wilayah wacana. Dengan penerapan ini, Gülen tampil sebagai seorang intelektual

12 Kalyoncu, A Civilian Response to Ethno-Religious Conflict: The Gülen Movement in Southeast Turkey (Lanham: Tughra Books, 2008), 19-40.

13 Turam, Between Islam and the State: The Politics of Engagement (Stanford: Stanford University Press, 2006), 61.

14 Zeki Saritoprak dan S. Griffith, "Fethullah Gülen and the 'People of the Book': A Voice from Turkey for Interfaith Dialogue," The Muslim World, Vol. 95, No. 3 (July 2005), 337-378.

15 M. Fethullah Gülen, Bangkitnya Spiritualitas Islam, terj. Fuad Saefuddin (Jakarta: Pepublika. 2012).

16 M. Fethullah Gülen, Membangun Peradaban Kita, terj. Fuad Saefuddin (Jakarta: Republika, 2013).

17 M. Fethullah Gülen, Qadar: Di Tangan Siapakah Takdir atas Diri Kita, terj. Ibnu Ibrahim Ba'adillah (Jakarta: Republika Penerbit, 2011).

18 Gülen, Towards the Lost, 86-87; Gülen, Toward a Global Civilization, 81-132; M. Fethullah Gülen, Pearls of Wisdom, terj. Ali Ünal (New Jersey: The Light Inc., 2006), 101-109.

${ }^{19}$ Gülen, Towards a Global Civization, 37. 
organik yang terlibat langsung dalam kancak praksis sebagai realisasi atas gagasan-gagasannya. Hal ini penting untuk dilihat agar diketahui seberapa signifikan daya usaha dan daya kontribusi gagasan Gülen tersebut dalam realitas kehidupan nyata. Kancah praksis juga menjadi muara untuk memahami urgensi dan eksistensi pemikiran seorang tokoh pemikir pada wilayah aksi. Untuk tujuan tersebut, penting menghadirkan pandangan para tokoh ilmuwan dan ulama terhadap penerapan pemikiran Gülen dalam kepaduannya dengan praktik.

Ibrahim al-Bayoumi Ghanem menyatakan, "kedua matanya selalu begadang dan dipenuhi tangisan karena banyak bersimpati dan merasa kasihan atas kondisi umat Islam dan manusia modern pada umumnya." Salman al-Awdah menyatakan, "ia menghadiri ribuan pengajian. Namun ia menghentikan pengajian-pengajiannya dengan tenang dan meneruskan pekerjaannya yang tenang dan berpengaruh itu. Kami menemukan murid-muridnya, jejaknya, dan kemampuannya dalam memberi pengaruh. Oleh karena itu ia disebut sebagai bapak al-Islâm alIjtimầ̂ dan bapak al-Islâm al-Wa'dî̀ Turki. Ahmad Syafi'i Ma'arif memperkuat pernyataan al-Awdah, "pada abad modern, muncul seorang warga Turki yang radius pengaruhnya demikian luas menglobal". ${ }^{20}$ Pandangan tiga tokoh ini berinti bahwa Gülen, sebagai seorang pemikir, memiliki empati yang kuat terhadap kondisi umat manusia saat ini, sehingga dia tergerak untuk melakukan tugas-tugas dakwah secara oral dan sekaligus praktis.

K.H. Salahuddin Wahid mengungkapkan ada relevansi pemikiran Gülen dengan konteks keislaman di Indonesia, ia menyatakan:

Bila kita baru pada taraf bicara tentang Islam rahmat li al-âlamîn, para aktivis Hižmet telah mewujudkan Islam rabmat li al-âlamîn dalam perbuatan di seluruh dunia, termasuk Indonesia. Mungkin Hoja Affandi (M. Fethullah Gülen) dapat disamakan dengan pendiri NU KH Hasyim Asy'ari dan pendiri Muhammadiyah KH Ahmad Dahlan. Ketiganya berkekuatan luar biasa memengaruhi masyarakat. Hanya dengan tokoh profetik semacam itu agama Islam di Indonesia akan menjadi sumber inspirasi dan penggerak dalam membenahi bangsa dan negara Indonesia. ${ }^{21}$

Komentar Gus Solah-sebutan akrab Salahuddin Wahidtersebut memperkuat terhadap penerapan pemikiran Gülen dalam kesatuannya dengan praktik. Komentar ini juga menunjukkan secara

${ }^{20}$ Gülen Chair, Mengenal Sosok Fethullah Gülen (Jakarta: Fethullah Gülen Chair UIN Syarif Hidayatullah, 2013), 75-76.

${ }^{21}$ Ibid., 76. 
tandas makna demitologi eksistensial Islam raḥmat li al-álamîn versi analisis historis kritis Bultmann. ${ }^{22}$ Dengan model analisis ini, Islam sebagai rạmmat li al-álamîn bukan mitos yang hanya didengungdengungkan oleh teks ajaran Islam, atau hanya diceramahkan, tetapi benar-benar terealisasi dalam praktik nyata untuk dunia. Pada komentar tersebut Gus Solah lebih menekankan demitologi eksistensial Islam untuk konteks Indonesia. Konteks ini, dengan nuansa demitologi eksistensial yang sama, diperkaya juga oleh komentar K.H. Abdurrahman Wahid sebagai berikut:

Saya rasa mengenai pendidikan, kita bisa belajar dari pengalaman Saî̀d Nursî dan Fethullah Gülen di Turki yang lebih menekankan pada pembentukan akhlak yang mulia. Ini sesuatu yang sangat penting apalagi bagi bangsa Indonesia, karena sekolah-sekolah kita ini sekarang hampa moral. Kehampaan moral ini telah mengakibatkan terjadinya berbagai pelanggaran yang ada di masyarakat, maraknya korupsi dan berbagai penyelewengan yang dilakukan birokrasi merupakan salah satu akibatnya. Ini menunjukkan bahwa ada krisis di dalam dunia pendidikan kaum Muslim di Indonesia. Karena itu saya rasa, belajar bagaimana mengembangkan akhlak yang baik dalam pendidikan kita menjadi sangat penting. Kita di Indonesia harus belajar dari teman-teman di Turki. ${ }^{23}$

Komentar Gus Dur-panggilan akrab Abdurrahman Wahid-ini menekankan pada ajakan untuk belajar kepada Nursî dan Gülen tentang pembentukan akhlak sebagai solusi atas problem kehampaan moral di Indonesia yang berakibat terjadinya berbagai pelanggaran norma di masyarakat, termasuk penyelewengan birokrasi.

2. Kemasan Pemikiran Baru yang Progresif

Pada era kontemporer ini, karakter yang menonjol gerakan Islam adalah "progresif". Menurut Omid Safi, Muslim progresif mendukung sikap kritis dan "multipel kritik" non-apologetik terhadap Islam dan modernitas. Ciri khas Muslim progresif saat ini adalah keterlibatan

\footnotetext{
22 Dengan penekanan pada eksistensialisme demitologis, Bultmann menggabungkan hasil kritisisme literer rasionalistik dengan eksistensialisme untuk membuat bentuk analisis kritis historis yang sangat radikal. Penegasan hal ini dapat ditemui pada dua karya Bulmann: (1) The New Testament and Mythology and other Basic Writings (Augsburg: Fortress Publishers, 1984) dan (2) Kerygma and Myth (London: S.P.C.K., HarperCollins, 2000).

23 Ibid. Lihat juga PASIAD, Mengenal Lebih Dekat PASLAD Indonesia (Jakarta: PASIAD Indonesia. t.th.), 19.
} 
ganda dengan jenis Islam dan modernitas, ditambah penekanannya pada aksi dan transformasi sosial yang konkret. ${ }^{24}$

Pada diri Gülen, progresivitasnya berupa pemaduan khazanah klasik dan modern ke dalam kemasan pemikiran baru yang dipropagandakan ke wilayah global. Pada kemasan baru ini, sebagaimana analisis Mark Scheel yang mengemukakan bahwa sebagai inspirasi untuk gerakan, Gülen sering disebut sebagai "Mahatma Gandhi Turki" dan "Rumi modern". Gülen adalah seorang guru, ulama, pemikir, penulis yang produktif dan penyair yang pengaruhnya luas dan signifikan. Topik pidato dan tulisan-tulisannya berkisar melampaui urusan agama untuk memasukkan pendidikan, ilmu pengetahuan, sejarah, ekonomi, dan keadilan sosial. Usahanya dalam dialog dan pendidikan antariman telah menjadi inovatif dan monumental. Gülen telah mengamati ada begitu banyak hal yang kita miliki bersama untuk ditekankan. Aspek unik dari gerakan yang diilhami oleh ajaran-ajarannya adalah bahwa hal itu mandiri dan berkembang biak sendiri, tidak tergantung pada karisma pendirinya melainkan pada kemanjuran visinya. ${ }^{25}$

Marcia Hermansen menjelaskan bahwa konsep praktik Islam Anatolia yang mengacu pada unsur-unsur seperti yang digambarkan oleh Jalâl al-Dîn al-Rûmî, yang pusat ritualnya terletak di Konya, kota Anatolia pusat. Al-Rûmî adalah pendiri tarekat Mevlevi atau tarekat Whirling Dervish yang sangat populer. Puisi-puisi al-Rûmî yang diliputi oleh cinta dan sering dibaca sebagai promosi pluralisme agama ${ }^{26}$ berkesesuaian dengan gerakan yang dimotori oleh Gülen. Hermansen melanjutkan penjelasannya, bahwa seorang pengamat gerakan Gülen menunjukkan bahwa al-Rûmî telah menjadi simbol dari posisi dialog dan toleransinya:

The philosophy that comes closest to this kind of humanism within the Muslim tradition is, of course, Sufism, and above all the teachings of Mevlana or Celaluddin Rumi (d. 1273). From this point of view it is no coincidence that there has been a general

24 Omid Safi, Progressive Muslims: On Justice, Gender, and Pluralism (Oxford: Oneworld, 2003), 1; Omid Safi, "What is Progressive Islam?", ISIM Newsletter 13/December 2003, 48.

${ }^{25}$ Mark Scheel, “A Communitarian Imperative: Fethullah Gülen’s Model of Modern Turkey,” Fountain Magazine, Issue 61/January-February 2008.

${ }^{26}$ Marcia Hermansen. "The Cultivation of Memory in the Gülen Community," dalam Ihsan Yilmaz (ed.), Muslim World in Transition: Contributions of the Gülen Movement (International Gülen Conference Proceedings), London, UK, 25-27 October 2007 (London: Leed Metropolitan University Press, 2007), 64. 
reorientation in recent years within the Gülen community away from Saîd Nursî (d. 1960), the original source of inspiration for the movement. Instead, there is greater interest in the works of Mevlana, the initiator of the whirling dervishes and a master of poetry and tevhid (mystic unity). ${ }^{27}$

Khazanah-khazanah klasik dalam kemasan baru pemikiran Gülen bersumber dari pilar-pilar inspirasi tokoh-tokoh lainnya selain al-Rûmî. Hal ini dipaparkan oleh Greg Barton dan Zeki Sariotoprak dan Sidney Griffith. Barton menjelaskan bahwa Gülen umumnya terlihat megacu langsung pada warisan intelektual Badiuzzaman Saî̀d Nursî, seorang sufi dan penulis yang berpengaruh dan sangat dicintai oleh Gülen. ${ }^{28}$ Selanjutnya Sariotoprak dan Griffith menjelaskan bahwa pemeriksaan terhadap tulisan Gülen mengungkapkan hal itu secara substansial dibangun di atas dasar yang diletakkan oleh Nursî. Pada gilirannya dasar itu mengarah ke sufi besar Anatolia al-Rûmî (w. 1276) dan penulis India Aḥmad Farûqî Sirhindî (1564-1624) dan Shah Walî Allah al-Dihlawî (1703-1762) di antara tokoh-tokoh lainnya. ${ }^{29}$

Para anggota hizmet Gülen, seperti ratusan ribu pengagum lain Nursî, bertemu secara rutin untuk membaca dan membahas komentar tematik multi-volume tentang al-Qur'ân, Risale-i Nur, atau Treatise of Light. Untuk alasan ini hizmet Gülen dipandang sebuah komponen yang signifikan dari gerakan Nurcu yang lebih luas. Gülen bukan hanya pengikut Nursî. Lebih jauh, ia adalah pemikir, penulis, dan pemimpin yang signifikan dalam kapasitasnya sendiri. Banyak karya Gülen secara esensial mengambil bentuk sintesis, reartikulasi, atau aplikasi yang segar dari karya-karya sebelumnya; dari Nursî dan lainnya. Seperti halnya Nursî dan banyak ulama Islam lain, Gülen sering merujuk dalam tulisannya dengan teladan hidup Nabi Muhammad untuk inspirasi dan arah. Namun demikian ada beberapa area yang signifikan yang spesifik, bahwa ia adalah seorang pemikir dan pemimpin yang mencolok orisinalitas dan inovasinya. Secara umum, seperti Nursî sebelumnya, ia dapat digambarkan sebagai seorang sufi dan mufakkir yang kaya dengan citra, nilai-nilai, dan ideide sufistik. Fokusnya pada hati (the inward being) sebagai tempat

\footnotetext{
${ }^{27}$ Elisabeth Özdalga, "Secularizing Trends in Fethullah Gülen's Movement: Impasse or Opportunity for Further Renewal," Critique (12, 2003), 70.

${ }^{28}$ Barton, "Preaching by Example", 655.

${ }^{29}$ Saritoprak dan Griffith, "Fetullah Gülen and the 'People of the Book': A Voice from Turkey for Interfaith Dialogue”, The Muslim World, Vol. 95, No. 3 (July 2005), 331-332.
} 
kebijaksanaan dan spiritualitas. Meskipun ia tumbuh di desa kecil Korucuk, bukan berarti ia dikelompokkan sebagai sufi tradisional, dan atau berafiliasi dengan tarekat sufi tertentu, lebih dari itu ia adalah seorang sufi yang independen. ${ }^{30}$

3. Penyebaran Nilai-nilai Kedamaian di Pelbagai Pelosok Dunia

Seiring dengan akselerasi penerbitan buku-buku M. Fethullah Gülen yang sempat diterjemahkan ke dalam 40 bahasa, secepat itu pula nilai-nilai kedamaian tersebar ke berbagai pelosok dunia. Nilainilai ini merupakan daya tarik yang berifat universal dan oleh karenanya ide-ide Gülen mudah tersebar dan diserap oleh masyarakat dunia. Pada era kontemporer ini, dalam hemat penulis, Gülen merupakan satu-satunya tokoh dunia Islam yang pemikirannya dapat dengan mudah diserap, diterima, bahkan didukung oleh hampir semua elemen penting masyarakat dunia di lebih dari 160 negara. Hal inilah yang menarik untuk ditelusuri, pesan-pesan unggulan yang disampaikan oleh Gülen dalam pemikirannya.

Gülen menyampaikan pesan unggulan yang menyangkut ruh Islam yang sesungguhnya; Islam adalah agama rahmat. Gülen juga menyampaikan gagasan utamanya untuk membangun masa depan dunia yang damai, saling menghormati, dan saling berkontribusi, tidak saling mencurigai dan merusak. Pesan unggulan Gülen ini disampaikan dengan pernyataannya tentang true Islam/Muslim: raḅmat li al-álamîn. Untuk mengawal pesan ini Gülen melakukan respons kuratif terhadap tindakan-tindakan yang merusak citra rahmat Islam dan citra positif Muslim. Oleh karena itu Gülen menentang bahkan mengutuk terorisme yang mengatasnakaman Islam. ${ }^{31}$ Gülen menyatakan secara terbuka bahwa terorisme ini merupakan bijacking of Islam (pembajakan Islam). ${ }^{32}$

4. Daya Serap Partisipatif oleh Masyarakat Global yang Besar

Urgensi dakwah sufistik dalam pemikiran Gülen juga penting diperhitungkan melalui besarnya daya serap partisipasipatif oleh masyarakat global. Semakin besar daya serap ini, semakin tinggi pula tingkat urgensi dan signifikansi peranan dakwah Gülen. Pemikirannya

\footnotetext{
30 Zeki Saritoprak, "Fethullah Gülen: A Sufi in His Own Way", dalam M. Hakan Yavuz dan John. L. Esposito (eds.), Turkish Islam and the Secular State: The Gülen Movement (Syracuse, New York: Syracuse University Press, 2003), 156-169.

31 "Fethullah Gülen: A Life Dedicated to Peace and Humanity-True Muslims Cannot be Terrorists," En.fGülen.com, 4 Februari 2002 (13 November 2016).

${ }^{32}$ Gülen, Toward a Global Civilization, 179.
} 
tidak hanya menembus pasar akademik dan tidak hanya persoalan peningkatan market penerbitan. Akan tetap justru yang jauh lebih penting adalah partisipasi masyarakat global terhadap ide-idenya. Partisipasi ini hadir dari pelbagai kalangan: unsur lintas agama (Islam, Kristen, dan Yahudi); lintas budaya dan ras (Timur dan Barat, kulit hitam dan putih, hidung mancung dan tidak mancung); profesional dan akademisi; sipil, politisi dan negarawan; sampai keterlibatan masyarakat umum dan para seniman internasional.

5. Kekuatan Akselerasi Penyebaran Nilai-nilai Sufistik yang Universal

Sejak tahun 1999 Gülen memulai promosi toleransi dan dialog ke dunia internasional. Promosi ini memperkenalkan nilai-nilai true Islam dan kontribusinya untuk membangun dunia baru yang damai dan saling menghargai. Promosi ini didukung pula oleh perangkat-perangkat publikasi berupa penulisan artikel dan penerjemahan buku-buku, dan media-media informasi dan komunikasi, konferensi-konferensi internasional, dan penyelenggaraan sekolah-sekolah di pelbagai kawasan dunia. Perangkat-perangkat ini mempunyai kekuatan untuk merangsang akselerasi penyebaran nilai-nilai sufistik universal: cinta; toleransi; pluralisme; dan humanisme ke berbagai pelosok dunia. Kekuatan akselerasi ini terbukti dengan cepat dan pesatnya perhatian juga partisipasi masyarakat dunia melalui intensitas international conferences and proceedings serta kajian-kajian dan penelitian-penelitian ilmiah tentang pemikiran Gülen dan bizmet movement. Hanya selang dua tahun sejak promosi ide-ide dialog dan toleransi sejak tahun 1999, international conferences digelar oleh masyarakat dunia, yaitu pada tahun 2001. Bahkan sejak saat itu Gülen menjadi perhatian besar dunia yang memenuhi kajian-kajian akademik dan media-media massa cetak, elektronik, dan online.

Sejak tahun 2001 sampai 2016 ini, sesuai dengan hasil pelacakan penulis, terdapat 30 even konferensi internasional tentang pemikiran Gülen dan bizmet movement. Gelaran akademik awal adalah Islamic Modernities: Fethullah Gülen and Contemporary Islam yang diselenggarakan di Georgetawn University, Washington, D.C., pada 26-27 April 2001. Gelaran terbaru yang ke-30 ialah Dimensions of an International Movement Fethullah Gülen and Hirmet: Centro Cultural Brasil-Turquia International Conference yang diselenggarakan di Sao Paulo University, São PauloBrazil, pada 18-19 Mei 2016. Di Indonesia, gelaran ke-21, International Fethullah Gülen Conference at Indonesia diselenggarakan di dua tempat yaitu: 
a) di Universitas Islam Negeri Syarif Hidayatullah, Jakarta, pada 9-10 Oktober 2010; dan b) di Universitas Indonesia Jakarta, pada tanggal 19-21 Oktober 2010.

\section{Praksis Dakwah Sufistik M. Fethullah Gülen}

Praksis dakwah sufistik Gülen telah memperlihatkan eksistensinya secara signifikan dalam perkembangan kehidupan masyarakat global dan khususnya dunia Islam sendiri. Eksistensi dapat dilihat pada enam poin berikut:

Poin pertama, praksis dakwah sufistik Gülen menyiapkan Golden Generation (GG) dengan proyeksi Ideal Human (IH) dan Ideal People (IP) dengan kurikulum pendidikan yang konstruktif, developmental, dan progresif secara luas. Dalam pandangan penulis, pemikiran Gülen sesungguhnya berisi megaproyek dalam usaha membangun dunia secara progresif. Proyek ini berkonsekuensi munculnya konsepkonsep GG, IH, dan IP. Konsep-konsep ini diberikan oleh Gülen untuk mengisi ruang-ruang peran nyata untuk penyelenggaraan megaproyek tersebut. Di sinilah Gülen merintis dan menginspirasi banyak orang untuk mendirikan dan membina lembaga-lembaga pendidikan di berbagai belahan dunia dengan kualitas terbaik yang terjangkau dari aspek ekonomi.

Data-data lapangan menunjukkan bahwa Gülen inspired schoolskadang digunakan singkatan GIS—eksis dengan pencapaian prestasi yang unggul dan para siswanya-termasuk mereka dari sekolahsekolah Gülen di Indonesia- sering memenangkan olimpiade-olimpiade sains sampai ke tingkat internasional. Sebagaimana pernyataan Ali Unal, sekolah-sekolah sangat sukses di olimpiade-olimpiade. Di Ajerbaijan, jumlah pendaftar sebanyak 7.000 anak, pendaftar yang diterima sebanyak 100 anak. ${ }^{33}$ Bukti-bukti kesuksesan GIS telah menarik minat besar masyarakat untuk menyekolahkan putra-putrinya di sekolah-sekolah tersebut. Bukti lain dari kesuksesan pendidikan di sekolah Gülen adanya deklarasi bahwa sekolah Turki yang paling sukses di Denmark. Informasi ini diambil dari berita yang dilansir oleh bizmetnews.com. ${ }^{34}$ Pada berita ini terdapat sisi lain yang menarik untuk diperhatikan kaitannya dengan dinamika teraktual relasi Gülen-Erdogan, yaitu despite Erdogan's efforts to shut down Gülen-inspired schools, success and prestige are

\footnotetext{
${ }^{33}$ Ali Unal, Wawancara, di Jakarta 15 Januari 2014.

34 "Turkish School Declared Most Successful in Denmark," bizmetnews.com, 25 August 2015; Source: Today's Zaman, August 12, 2015 (14 Desember 2016).
} 
upheld (meskipun upaya Erdogan untuk menutup sekolah-sekolah yang terinspirasi oleh Gülen, kesuksesan dan prestasi ditegakkan).

Penyelenggaraan pendidikan di sekolah-sekolah Gülen terkait dengan penyiapan sumber daya manusia (SDM) untuk mengisi peranperan strategis dalam megaproyek yang sedang digagas dan digulirkan oleh Gülen. SDM yang dipersiapkan, diawali dari penciptaan GG, selanjutnya mengarah ke IH dan IP sebagai target ke depan yang sedang ia upayakan secara global. Konsep-konsep tentang GG, IH, dan IP dinyatakan oleh Gülen dalam buku-bukunya. Konsep GG dinyatakan dalam buku Towards the Lost Paradise ${ }^{35}$ dan muncul dalam sejumlah kajian sebagaimana Yetkin Yildirim dan Suphan Kirmizialtin ${ }^{36}$, Aland Mizell $^{37}$, Abbas Djavadi ${ }^{38}$, dan kajian-kajian lainnya. Konsep IH dinyatakan dalam buku Toward a Global Civilization of Love and Tolerance. $^{39}$ Selanjutnya konsep IP dinyatakan dalam buku Pearls of Wisdom..$^{40}$

Dalam konteks GG, sekolah Gülen telah menghasilkan standar pendidikan yang tinggi dalam waktu singkat sejak pendiriannya. Visi pendidikan Gülen adalah "perkawinan pikiran dan hati”. Oleh karena itu, bersamaan dengan keunggulan akademik dalam pendidikan, GIS menanamkan nilai-nilai etika universal. Visi ini dapat membantu pembangunan dunia yang damai di mana "orang mencintai cinta dan membenci kebencian". GIS mendukung visi pengasuhan GG yang akan menghindari clash of civilizations (benturan peradaban) yang diprediksi, dan mencapai keharmonisan dan perdamaian global. Terkait dengan visi ini, Gülen menyatakan:

The world is to be saved by that "golden" generation who represent the Divine Mercy, from all the disasters, intellectual, spiritual, social and political, with which it has long been afflicted. The world will come back, through their efforts, to its "primordial" pattern, on which God created it, and be purified of all kinds of deviation and ignorance, so that people

\footnotetext{
35 Gülen, Towards the Lost Paradise, 86-87.

36 Yetkin Yildirim dan Suphan Kirmizialtin, "Fethullah Gülen's Golden Generation: Integration of Muslim Identity with the World through Education," pada the AMSS $33 r d$ Annual Conference at George Mason University Arlington Campus-Virginia on September 24-26, 2004.

${ }^{37}$ Aland Mizell, "The End of Fethullah Gülen's Utopian Society: The Awaited Golden Generation,” kurdistantribune.com, June 27, 2014 (18 Desember 2016).

38 Abbas Djavadi, “Turning Away From Gülen's 'Golden Generation',” www.rferl.org, August 29, 2016 (16 Desember 2016).

${ }^{39}$ Gülen, Toward a Global Civilization, 81-132.

${ }^{40}$ Gülen, Pearls of Wisdom, 101-109.
} 
may rise to "the highest of the high" on the ladder of belief, knowledge and love, supported against the heavens by the Divine Message.

Humankinds have never been so wretched as they are today. They have lost all their values: the "table of art and literature" is "vandalized" by drunks; thought is capital wasted in the hands of people suffering from intellectual poverty; science is a plaything of materialism; and the products of science are tools used in the name of unbelief. Amid such disorder and bewilderment, the people neither know their destination in the world nor the direction to follow to reach that destination. ${ }^{41}$

Gülen menyatakan peran strategis GG untuk menyelamatkan dunia yang telah lama mengalami penderitaan bencana, intelektual, spiritual, sosial dan politik. Melalui usaha ini, masyarakat dunia dapat naik ke tangga tertinggi keyakinan, pengetahuan dan cinta, yang didukung oleh pesan Tuhan. Peran strategis ini dibutuhkan karena kondisi manusia saat ini telah kehilangan semua nilai-nilai mereka: "papan seni dan sastra" telah "dirusak" oleh pemabuk; pikiran menjadi modal yang terbuang di tangan orang yang menderita kemiskinan intelektual; sains menjadi mainan materialisme; dan produk ilmu pengetahuan menjadi alat yang digunakan atas nama ketidakimanan. Di tengah kekacauan dan kebingungan itu, orang tidak juga mengetahui tujuan hidup mereka di dunia maupun arah untuk mencapai tujuan itu. Agai menganalisis pandangan Gülen ini, bahwa generasi GG ini akan dapat mengatasi ideologi dari masa lalu. Barat dan Timur tidak dapat merantai kakinya atau menangkapnya. Demikian juga, "isme" yang menentang asal jiwanya tidak akan mengubah arah dari jalan atau bahkan menyentuhnya. ${ }^{42}$

Sedangkan Nelson dan Polat memberikan analisisnya tentang visi transenden GG dan dan manifestasinya. Menurut Nelson, visi transenden Gülen untuk menciptakan GG adalah satu-satunya alasan untuk menjadi founder bagi ratusan sekolah di seluruh dunia. Selanjutnya Polat menjelaskan bahwa GG terdiri dari "generasi individuindividu yang ideal universal, individu yang mencintai kebenaran, yang mengintegrasikan spiritualitas dan pengetahuan, yang bekerja untuk menguntungkan masyarakat." Gülen menjelaskannya seperti orang zul-cenabeyn, yang berarti "orang yang memiliki dua sayap", dan memanifestasikan "perkawinan pikiran dan hati", penggabungan dari

\footnotetext{
${ }^{41}$ Gülen, Towards the Lost Paradise, 86-87.

42 Bekim Agai, “The Gülen Movement's Islamic Ethic of Education” dalam M. Hakan Yavuz dan John L. Esposito (eds.), Turkish Islam and the Secular State (Syracuse, NY: Syracuse University Press, 2003), 58.
} 
nilai-nilai etika yang universal dengan ilmu dan pengetahuan. Hal ini akan memelihara "orang-orang yang benar-benar tercerahkan", yang dimotivasi oleh cinta dan bertugas melayani kemanusiaan. ${ }^{43}$

Dalam sumber asli konsep Gülen, GG dipersiapkan untuk penciptaan Ideal Human (IH) yang kelak mengisi peran strategis dalam sejarah global. Gülen memberikan profil definitif bahwa IH adalah orang-orang yang mempercayakan keseimbangan pikiran dan pengalaman, tetapi memberikan perhatian besar terhadap kesadaran dan inspirasi. Mereka mengejar kesempurnaan dalam setiap hal, menentukan keseimbangan antara dunia dan akhirat, dan mengawinkan hati dengan intelek. Lebih jauh, IH ini memiliki karakter sebagai berikut:

Pertama, mereka memiliki integritas yang bebas dari pengaruhpengaruh luar. Tidak ada kekuatan duniawi yang mampu mengikat mereka. Tidak ada "isme-isme" modern yang mampu memaksa mereka keluar dari jalur mereka. Mereka berpikir dan bertindak secara bebas untuk sebuah kebebasan mereka sebagai porsi pelayanan kepada Tuhan. Pertimbangannya, daripada mereka meniru orang-orang lain, mereka lebih mempercayakan dinamika orisinal yang bersumber dari kedalaman sejarah.

Kedua, mereka berpikir, menelusuri, percaya, dan dipenuhi oleh kesenangan spiritual. Ketika mereka menggunakan secara penuh fasilitas-fasilitas modern. Mereka tidak merusak nilai-nilai tradisional dan spiritual mereka dalam pengembangan dunia mereka sendiri. ${ }^{44}$

Gambaran ideal IH ini diberikan oleh Gülen dengan kesadaran bahwa kehadirannya bukan hal yang mudah, tetapi dapat terjadi dari kelahiran manusia-manusia yang diberkati yang akan memberikan kepada dunia sebuah generasi brilliant baru. Hal ini seperti air hujan yang secara perlahan menyirami kumpulan awan, dan sumber-sumber air muncul dari dalam tanah, demikian juga "bunga-bunga" dari generasi baru ini akan muncul suatu saat. ${ }^{45}$ Ia juga menempatkan

\footnotetext{
${ }^{43}$ Charles Nelson, "Fethullah Gülen: A Vision of Transcendent Education" Islam in the Contemporary World: The Fethullah Gülen Movement in Thought and Practice (International Coference), November 12-13, 2005, Rice University, Houston; Polat, "Gülen-Inspired Schools in Australia: Educational Vision and Funding," Paper dipresentasikan pada From Dialogue to Collaboration: The Vision of Fethullah Gülen and Muslim-Christian Relations (Gülen Conference), Australian Catholic University, Melbourne, July 15-16, 2009, 4.

${ }^{44}$ Gülen, Toward a Global Civilization, 81 .

${ }^{45}$ Ibid.
} 
konsep IH sebagai "manusia baru" dalam dialektikanya dengan realitas periode sejarah pada dua-tiga abad terakhir. Pada kurun waktu itu perkembangan ilmu dan teknologi telah mencerminkan sebuah keterputusan dunia global dari nilai-nilai tradisional, terarah ke nilainilai yang berbeda dan fantasi spekulatif. Oleh karenanya, harapan Gülen_-dengan penguatan promosi—abad yang akan datang menjadi abad iman dan nilai-nilai moral, suatu abad yang mencerminkan kebangkitan dan kebertahanan untuk orang-orang yang beriman (the New Age of Faith and Moral V alues).

Sampai pada tahap visi tentang IH setelah GG, Gülen tidak berhenti. Dia melanjutkannya ke konsep visional tentang Ideal People (IP) pada bukunya Pearls of Wisdom. Dalam buku ini, Gülen menjelaskan bahwa IP memiliki karakter sebagai berikut:

Pertama, level people of service, orang atau masyarakat yang melayani orang lain, siapa pun, dengan penuh tanggung jawab moral dan dedikasi sepenuhnya, dengan hati yang tulus, penuh hormat, dengan landasan syukur kepada Tuhan dan mempertanggungjawabkan semua pengabdiannya kepada Tuhan. Dalam layanannya, mereka mengembangkan sikap-sikap moderat dan toleran; semangat, tekun dan percaya diri; tulus dan rendah hati; rela berkorban meskipun nyawa taruhannya demi kecintaannya terhadap dedikasi.

Kedua, level essentials of the way, orang atau masyarakat yang lebih memilih nilai yang suci daripada semua keinginan duniawi dan hewani. Mereka teguh dalam kebenaran. Pengorbanannya diberikan untuk prioritas kesejahteraan masyarakat saat ini dan akan datang, tanpa ambisi terhadap penghargaan dan posisi apapun. Pengutamaan kepada orang lain adalah penting dari cara suci melayani kebenaran. Mereka yang memimpin jalan memberi contoh yang baik bagi pengikutnya. Mereka juga berusaha untuk mewujudkan kebenaran dengan kejujuran, kepercayaan, kesadaran tugas, persepsi yang tinggi, kesadaran situasi dan kesucian mutlak agar tidak menjadi musibah bagi orang-orang yang mengikutinya.

Ketiga, level heroes of love, orang atau masyarakat yang hatinya meluap dengan cinta, membangun dunia yang bahagia dan mencerahkan masa depan. Bibir mereka tersenyum dengan cinta, hati mereka penuh dengan cinta, mata mereka memancarkan cinta dan manusia yang paling lembut perasaannya. Mereka melayani untuk meningkatkan kesejahteraan orang lain dan memberikan manfaat kepada masyarakat. 
Keempat, level personal integrity, orang atau masyarakat yang ingin mereformasi dunia, pertama kali mereka harus mereformasi diri sendiri. Jika mereka ingin memimpin orang lain untuk dunia yang lebih baik, mereka harus menyucikan dunia batin mereka dari kebencian, dendam dan kecemburuan dan menghiasi dunia luar mereka dengan kebajikan. Kata-kata dari orang-orang yang tidak mampu mengontrol dan mendisiplinkan diri dan belum menyempurnakan perasaannya, mungkin tampak menarik pada awalnya. Namun, jika mereka berhasil menginspirasi orang lain, sentimen mereka yang membangkitkan akan segera layu.

Kelima, level ideal spirits, orang atau masyarakat yang berusaha untuk mencerahkan orang lain, mencari kebahagiaan untuk mereka dan mengulurkan tangan untuk membantu mereka, memiliki semangat seperti malaikat penjaga. Mereka berjuang dalam bencana yang menimpa masyarakat, berdiri untuk menghadapi "badai," bergegas untuk memadamkan "api" dan selalu waspada terhadap kemungkinan guncangan. ${ }^{46}$

Pada akhirnya, konsep Gülen tentang IP ini memberikan bahan mayor bagi profil prinsip-prinsip dakwahnya sebagaimana pembahasan di muka. Agar konsep yang telah diulas menjadi sederhana, penulis berikhtiar untuk menggambarkan konsep ideal ala Gülen pada bentuk bagan berikut.

\section{Gambar 1:}

\section{Bagan Konsep Ideal ala Gülen}

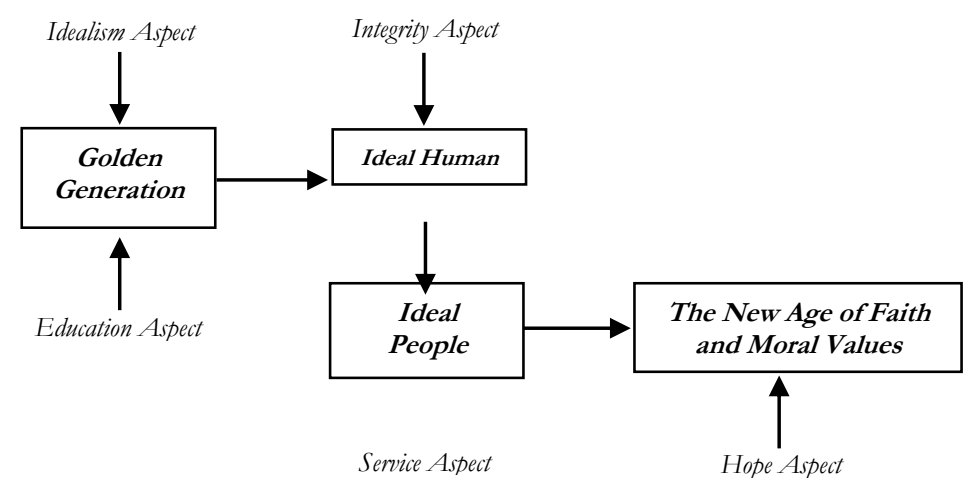

Pada gambar di atas tampak bahwa konsep-konsep Gülen tentang GG, IH dan IP memperlihatkan adanya aspek-aspek utama yang berhubungan secara sistematis. Aspek-aspek ini adalah idealisme dan

${ }^{46}$ Gülen, Pearls of Wisdom, 101-109. 
pendidikan untuk GG, integritas kepribadian untuk IH dan pelayanan untuk IP. Relasi sistematis ini mengarah pada pencapaian harapan berupa keterwujudan the new age of faith and moral values.

Adapun poin kedua, praksis dakwah sufistik Gülen menyerap berbagai dukungan moral, fasilitas, bahkan finansial dari berbagai kalangan secara luas. Dukungan moral dan fasilitas terhadap gerakan Gülen hadir dari berbagai elemen masyarakat global; tokoh-tokoh agama dan masyarakat, para akademisi, negarawan, seniman, pengusaha, sampai masyarakat umum. Dukungan moral ini juga melibatkan jaringan institusi dialog antaragama dan antarbudaya dan forumforum kajian. Secara kelembagaan formal, jaringan institusi ini terjalin atas kerjasama dengan lembaga-lembaga sebagaimana penjelaan singkat di bawah ini:

1. Rumi Forum: for Interfaith Dialogue and Intercultural Understanding, Address: 750 1st St. N.E., Suite 1120 Washington DC 20002; Phone: +1 (202) 429 1690; Website: http://rumiforum.org/; Email: info@rumiforum.org.

2. Gülen Institute: United Around High Human Values; Address: 110HA Social Work Building.University of Houston, 4800 Calhoun Rd. Houston, TX 77204; Website: http://www.Güleninstitute.org/; Activities: research grants and scholarships; organizes lecture series; facilitates workshops and panel discussions that attract academics from around the world; cultural exchange trips to graduate students.

3. Nordic Gülen Institute (NGI); Address: Box 2041, 14502 Norsborg; Phone: 802489-2468; Area interes: dialogue, education, integration, active citizienship; Website: http://www.nordicGüleninstitute.org/; email: info@nordicGüleninstitute.org.

4. Gülen Institute Youth Platform; Address: 110HA Social Work Building. University of Houston, 4800 Calhoun Rd. Houston, TX 77204. Website: http://gülenyouthplatform.org/; Email: youth platform@Güleninstitute.org

5. Fethullah Gülen Chair (FGC) di Universitas Islam Negeri Syarif Hidayatullah Jakarta; Address: Jalan Ir. Haji Juanda No. 95, Ciputat, Cempaka Putih, Ciputat Timur, Kota Tangerang Selatan, Banten 15412.

6. Fethullah Gülen Chair-ACU (Australian Catholic University); Address: Level 4, 250 Victoria Parade, East Melbourne, Victoria, 3002, Australia, Locked Bag 4115 Fitzroy MDC VIC 3065; Phone:: +61 [3] 9953 3920, Fax: +61 [3] 9417 3259; Links: Pontifical Council 
for Interreligious Dialogue: http://www.vatican.va/roman_curia /pontifical_councils/interelg/index.htm, Australian Intercultural Society: http://www.intercultural.org.au/.

7. The Fethullah Gülen Chair for Intercultural Studies at Katholieke Universiteit Leuven (inaugurated on 7 December 2010); Address: Oude Markt 13, 3000 Leuven, Belgia; Phone: +32 16324010; Website: http://Gülenchair.be/.

8. Dialoog Academie: Address: Rochussenstraat, 3021 NT Rotterdam; Contactpersoon: mevr. Iris Creemers; Phone: 010 4257533; Website: www.dialoogacademie.nl; E-mail: info@dialoogacademie.nl;

9. "Gülenist non-profits and organizations" (A Guide to the Gülen Movement's Activities in the US) yang ditulis oleh C.A.S.I.L.I.P.S. (Citizens Against Special Interest Lobbying in Public Schools), berisi daftar lengkap (dengan alamat situsnya) lembaga-lembaga nonprofit dan organisasi-organiasi Gülenis di AS, pada http://turkishinvitations.weebly.com/Gülenist-non-profits.html, last updated July 28, 2013.

10. Fethullah Gülen Forum: for a better understanding; Website: http: //www.fethullah Gülenforum.org/

Dukungan finansial gerakan Gülen bersumber dari kalangan masyarakat luas. Ebaugh dan Koc menjelaskan hasil penelitiannya di Turki dan Houston, Texas tentang sumber-sumber pendapatan dana untuk kegiatan gerakan Gülen. Pokok-pokok hasil kajian ini penulis sajikan sebagai berikut:

1. Jumlah dan ruang lingkup proyek yang terinspirasi oleh ide-ide Gülen dan dioperasikan oleh para pendukungnya sangat luas dan terus berkembang: a) sekolah-sekolah di Turki dan di seluruh dunia; b) rumah-rumah sakit swasta (enam RS paling top); c) 15 universitas besar; d) ratusan asrama siswa dan kursus persiapan ujian universitas nasional di Turki; e) organisasi bantuan internasional; f) yayasan wartawan dan penulis; g) konglomerat media yang mencakup koran Zaman dengan pembaca terbesar dari setiap koran di Turki; h) Aksiyon, majalah berita yang banyak dibaca; i) stasiun televisi Samanyolu; j) Kaynak Holding Group, produsen terbesar, distributor dan pengekspor produk pendidikan Turki; k) TUSKON, sebuah LSM regional yang mewakili lebih dari 10.000 pengusaha; l) Bank Asya; m) agen perjalanan; dan n) ratusan organisasi lokal di seluruh dunia yang mensponsori 
konferensi, ceramah dan perjalanan antaragama/antarbudaya antar ke Turki.

2. Dana untuk kegiatan gerakan disediakan oleh jutaan orang di seluruh dunia yang berkomitmen untuk cita-cita yang dipromosikan oleh Gülen. Dasar strategi penggalangan dana dalam gerakan terletak pada pembentukan lingkaran lokal pengusaha, guru, kepala sekolah, profesional dan mahasiswa yang bertemu bersama secara teratur untuk mendiskusikan karya-karya Gülen dan mempertimbangkan bagaimana cita-citanya dapat diterapkan di komunitas lokal mereka.

3. Data dari satu lembaga lokal yang terinspirasi oleh Gülen di Houston, Texas, yang mengumpulkan ribuan dolar per tahun dari anggota lokal, sebagian besar dari para siswa pada tunjangan pendidikan yang kecil.

4. Yayasan Kimse Yok Mu Aid dan Solidaritas -organisasi yang terinspirasi oleh Gülen di Turki- merupakan salah satu organisasi bantuan terbesar di Turki dan mengumpulkan jutaan dolar per tahun.

5. Perilaku memberikan dana tidak hanya terjadi di kalangan pengusaha kaya, tapi juga semua orang dalam gerakan dan kebanyakan orang memberikan antara 5-20\% dari pendapatan tahunan mereka, dengan rerata $10 \%$. Dalam dua kelompok pengusaha kaya, hal itu tidak biasa bagi mereka untuk memberikan \$3-4 juta per tahun pada berbagai proyek. Banyak dari mereka yang membagi pendapatan mereka menjadi sepertigaan; sepertiga dimasukkan kembali ke dalam bisnis, sepertiga digunakan untuk mendukung keluarganya dan sepertiga sisanya diberikan kepada proyek-proyek gerakan.

6. Ada kesamaan sumber daya keuangan pada tingkat akar rumput, misalnya yayasan bantuan yang menerima sumbangan dari lebih 635.000 orang di tahun 2007. Sumber daya keuangan dari gerakan Gülen berasal dari individu yang mendukung kegiatan gerakan.

7. Ada beberapa klaim bahwa gerakan ini didanai oleh negara-negara yang berbeda atau dinas rahasia. Misalnya, beberapa orang mengklaim gerakan didanai oleh CIA, sementara yang lain mengklaim, itu didanai oleh beberapa negara-negara Islam. Klaim ini semua tidak berdasar dan tidak ada bukti yang pernah dibuat untuk mendukungnya. 
8. Gülen, selain mendorong orang untuk menyumbangkan uang, ia tetap terpisah dari semua keterlibatan keuangan dan tidak mendorong mereka yang mensponsori proyek untuk mengawasi penggunaan kontribusi mereka. Sikap ini telah membangun kepercayaan dan keyakinan dalam kejujuran dan integritas Gülen. ${ }^{47}$

Bahkan di luar lingkaran aktivis gerakan, Bill Gates-dikenal sebagai raja windows - tergerak juga untuk menyumbangkan dana untuk sekolah-sekolah Gülen. Hal ini dijelaskan oleh Paul L. Williams dalam tulisannya Bill Gates Funds Gülen Islamist Movement, Williams menjelaskan bahwa Gates menempati peringkat orang terkaya ketiga di planet bumi. Pada tahun 2007, melalui proyek Sekolah Tinggi Texas, Gates Foundation menyumbang \$ 10.550 .000 ke Cosmos Foundation, sebuah firma Gülen yang mengoperasikan 25 charter schools yang didanai oleh publik di Texas. Pada saat ini, ada 85 madrasah (sekolah Islam) Gülen di Amerika Serikat dan semua beroperasi dengan dana publik. ${ }^{48}$

Adapun poin ketiga, praksis dakwah sufistik Gülen berkontribusi terhadap peningkatan citra positif Islam dan Muslim. Hal ini terkait dengan penurunan citra positif Islam dalam pandangan masyarakat dunia, khususnya Barat. Pada era kontemporer, wajah polaris Islam ramah dan garang ${ }^{49}$ lebih menonjol pada wajah garangnya dengan adanya tragedi $9 / 11^{50}$, pengeboman di beberapa wilayah oleh teroris yang diklaim atau menyatakan diri sebagai penanggungjawab dari kalangan Muslim radikal ${ }^{51}$ dan kasus yang teraktual, yaitu Islamic State of Iraq and Syria (ISIS). Meskipun pada kenyataan historis terlihat

47 Ebaugh, "Financial Dimension: Financing the Gülen-Inspired Projects," 101-109;

48 Paul L. Williams, "Bill Gates Funds Gülen Islamist Movement," dalam http://globalslaves.blogspot.co.id/2010/12/bill-gates-funds-Gülen-islamist.html, May 24, 2010 (1 Januari 2017).

49 Polarisasi dua wajah ramah dan garang Islam dipaparkan oleh semisal karya Stephen Schwartz, The Two Faces of Islam: The House Sa'ud from Tradition to Terror (New York: Doubleday, 2002).

${ }^{50}$ Deskripsi kritis tentang tragedi 9/11 dapat dilihat pada Abû Rabî', "A postSeptember 11 Critical Assessment of Modern Islamic History" dalam Markham dan Abu Rabi' (Ed.), 11 September: Religious Perspective on the Causes and Consequences (Oxford: Oneworld Publications. 2002).

51 Joseph I. Lieberman dan Susan M. Collin, A Ticking Time Bomb: Counter Terrorism Lesson from the U.S. Government's Failure to Prevent the Fort Hood Attact (A Special Report) Washington D.C.: U.S Senate Committee on Homeland Security and Governmental Affairs, 2011); Paul R. Pillar, Terrorism and U.S. Foreign Policy with a New Introductory Essay on Counterterrorism Since 9/11 (Washington D.C.: The Brookings Institution, 2001). 
bahwa terorisme bukan hanya dominasi gerakan fundamentalisme dalam Islam sebagaimana hasil pemetaan Juergensmeyer (guru besar Sosiologi dan direktur Global and International Studies Universitas California di Santa Barbara, Amerika Serikat). ${ }^{52}$ Akan tetapi frekuensi dan intensitas terorisme pada era kontemporer tampak menonjol dilakukan oleh gerakan tersebut dengan klaim-klaim politis yang muncul ke permukaan media massa dan kajian-kajian ilmiah. Kehadiran Gülen dan gerakan hiæmet-nya dengan dakwah sufistiknya telah memberikan kontribusi yang besar untuk mengurangi sedikit demi sedikit kesan Islam teroris dan meningkatkan citra positif Islam dan Muslim pada era kontemporer di berbagai belahan dunia.

Adapun poin keempat, praksis dakwah sufistik Gülen berkontribusi terhadap peningkatan citra kontributif Muslim sampai ke wilayah global. Data-data yang terpaparkan di muka memperlihatkan secara tandas bahwa praksis dakwah sufistik Gülen memberikan kontribusi yang besar terhadap peningkatan citra kontributif Muslim. Muslim mampu berkontribusi-di bidang-bidang sistem pendidikan, pembangunan moral, penguatan ekonomi, demokrasi, solusi epistemologis ilmu pengetahuan, rekonsiliasi antaragama dan antarbudaya-dan memperoleh dukungan besar secara global sebagaimana ditunjukkan oleh kajian Hunt dan Aslandogan ${ }^{53}$, kajian Conway $^{54}$, kajian-kajian Saritoprak, Pratt, Uygur, Keles dan Osman ${ }^{55}$ dan kajian Greg Barton, dan kawan-kawan. ${ }^{56}$ Muslim bukan hanya

52 Lihat mark Juergensmeyer, Terror in the Mind of God: The Global Rise of Religious Violence: Comparative Studies in Religion and Society, 13 (Berkeley, CA: University of California Press, 2000), xi, 116-118.

${ }^{53}$ Robert A. Hunt dan Yuksel A. Aslandogan, Muslim Citizens of the Globalized World: Contributions of the Gülen Movement (New Jersey: IID dan The Light Inc., 2007).

54 Trudy D. Conway, Cross-cultural Dialogue on the Virtues: The Contribution of Fethullah Gülen (New York: Springer, 2014).

55 Zeki Saritoprak, "Fethullah Gülen and His Global Contribution to Peace Building" (632-642); Douglas Pratt, "Islamic Prospects for Inter-Religious Dialogue: The Contribution of Fethullah Gülen" (391-427); Selcuk Uygur, "Islamic Puritanism" as a Source of Economic Development: Contributions of the Gülen Movement"; Keles, "Contributions of the Gülen Schools in Kyrgyzstan" (176-186); dan Muhammad Nawab Osman, "Gülen's Contribution to a Middle Way Islam in Southeast Asia," (334-406) dalam Ihsan Yilmaz (ed.), Muslim World in Transition: Contributions of the Gülen Movement (International Gülen Conference Proceedings), London, United Kingdom, 25-27 October 2007 (London: Leed Metropolitan University Press, 2007).

${ }^{56}$ Greg Barton, Paul Weller, dan Ihsan Yilmaz (eds.), The Muslim World and Politics in Transition: Creative Contributions of the Gülen Movement (London: Bloomsbury Publishing, 2013). 
konsumen dan objek di bidang-bidang tersebut tetapi sebagai aktor. ${ }^{57}$ Melalui kontribusi ini, Islam bukanlah oposisi tetapi mitra bagi agamaagama dan budaya-budaya lain.

Pada era modern, memang dapat dijumpai bahwa melalui dakwah sufistik citra kontributif Islam terjadi pada beberapa bidang kehidupan baik sosial maupun politik. Misalnya Tarekat Sanûsiyah telah berperan dalam peningkatan citra kontributif Islam dan Muslim melalui perjuangan nasionalismenya untuk merespons kolonialisme awalmodern dan mampu berperan dalam pembangunan bangsa Libya. Contoh kedua dalam jangkauan wilayah yang lebih luas, yakni di Chechnya, misalnya, sufi telah diidentifikasi sebagai oposisi terhadap Kremlin dan berfungsi sebagai kendaraan untuk pemulihan hubungan pro-Rusia. ${ }^{58}$

Adapun poin kelima, praksis dakwah sufistik Gülen berkontribusi terhadap pembangunan moral masyarakat dunia, dengan penekanan pada cinta, toleransi, pluralisme dan humanisme, melalui dialog-dialog, lembaga-lembaga pendidikan dan studi, program-program layanan dan pusat-pusat gerakan dakwah. Sebagian fakta untuk hal ini dipaparkan oleh Helen Rose Ebaugh. Menurut Ebaugh, semua organisasi yang terinspirasi oleh Gülen, apakah rumah sakit, sekolah, organisasi bantuan, media, atau pusat-pusat institusi telah menyerap ide-de: a) mendidik pemuda dalam masyarakat untuk menggabungkan spiritualitas dengan pelatihan intelektual; b) menyediakan pendidikan modern di semua bidang kehidupan; menekankan nasionalisme Turki dan apresiasi masa lalu Turki; c) terlibat dalam dialog antarbudaya dan antaragama; d) toleran terhadap ide dan pendapat yang berbeda; e) cinta dan hormat kepada semua umat manusia; f) berperspektif global dan ramah; dan g) memberikan pelayanan dan membantu kepada sesama manusia. ${ }^{59}$

Pada bagian ini penulis memandang penting untuk memaparkan layanan terapi psikologis di Irak yang terkait dengan kontribusi gerakan Gülen terhadap pembangunan moral masyarakat dunia sebagaimana dimaksudkan oleh Ebaugh. Ebaugh mendeskripsikan bahwa sekolah-sekolah dan rumah-rumah sakit yang dibuat oleh

57 Jean Jacques Waardenburg, Muslim as Actors; Islamic Meanings and Muslim Interpretations (Berlin: Walter de Gruyter Gmbh \& Co., 2007).

58 Martin van Bruinessen dan Julia Day Howell (eds.), Sufism and the 'Modern' in Islam (New York: I.B. Tauris \& Co. Ltd., 2007), 10.

${ }^{59}$ Martha Ann Kirk, Hope and Healing: Stories from Northern Iraq Where Persons Inspired by Fethullab Gülen Have Been Serving (Turkey: Gülen Institute, 2011), 44. 
Muslim yang terinspirasi oleh Gülen telah menyumbang secara substansial untuk memberikan layanan terapi psikologis di daerahdaerah yang telah dilanda kekerasan seperti halnya negara Irak. Layanan terapi ini dimaksudkan untuk memberikan kontribusi pembangunan moral masyarakat dunia dengan penekanan pada cinta, toleransi, pluralisme dan nilai-nilai kemanusiaan yang tinggi. Layanan kepada para siswa dilaksanakan bukan hanya dengan pengajaran dan bimbingan tetapi juga dengan teladan. ${ }^{60}$

\section{Penutup}

M. Fethullah Gülen adalah seorang tokoh karismatik dan pendakwah dengan pendekatan sufisme, di samping sebagai penulis dan aktivis pendidikan. Kontribusi dakwah sufistik Gülen sangat signifikan pada era kontemporer dalam pemikiran dan praksis. Pertama, pemikiran dakwah sufistik Gülen bermuara dari pandangannya tentang sufisme sebagai kehidupan spiritual dan perjalanan seumur hidup bagi manusia untuk mencapai kebahagiaan di dunia dan akhirat. Kedua, praksis dakwah sufistik Gülen termanifestasi ke dalam praktik dakwah dengan sistem metodis yang menekankan gerakan hizmet dengan taktik filantropis dan media kontemporer. Ketiga, pemikiran dan praksis tersebut dapat dibentuk ke dalam konstruksi ideal dakwah sufistik Gülen yang berbasis idealitas dakwah-rahmat global-dari al-Qur'ân dan Sunnah Nabi dengan penekanan pada praksis hizmet yang bertujuan terciptanya the Golden Era (Age of Happiness).

Terdapat tanda-tanda kemungkinan untuk disusun konsep baru tentang sufisme era kontemporer dengan penonjolan pada core theme yang dapat memperkaya nomenklatur khususnya ilmu dakwah dan umumnya Islamic studies. Apa yang diupayakan oleh Gülen secara nyata memberi kontribusi yang signifikan untuk perkembangan perspektif ilmu Agama, khususnya dakwah. Meskipun apa yang telah ia lakukan bukan sama sekali baru, tapi pemikiran dan aksi Gülen memiliki karakteristik yang khusus dan spesifik, yakni visi the New age of Faith and Moral Values menuntutnya memikirkan konsep pencapaiannya, yaitu yang terkonsep dalam tiga istilah tahapan: Golden Generation (GG); Ideal Human (IH); dan Ideal People (IP). Tiga tahapan ini menjadi megaproyeknya yang sedang hangat dibicarakan oleh publik internasional, istilah dakwah sufistik kemudian dipilih dalam tulisan ini karena melihat cakupan pendayagunaan potensi manusia untuk menjadi ideal bagi dirinya, masyarakatnya dan seluruh manusia lain

${ }^{60}$ Ibid., 44-45. 
dengan nuansa yang sangat sufistik, berdasar pada nilai-nilai sufisme seperti cinta, toleransi; pluralisme; dan humanisme.

\section{Daftar Rujukan}

Abu-Rabi', Ibrahim M. "A post-September 11 Critical Assessment of

Modern Islamic History" dalam Ian Markham dan Ibrahim, M.

Abu Rabi' (Ed.), 11 September: Religious Perspective on the Causes and Consequences. Oxford: Oneworld Publications, 2002.

Agai, B. "The Gülen Movement's Islamic Ethic of Education," dalam

M. Yavuz dan John L. Esposito (eds.), Turkish Islam and the Secular State. Syracuse, New York: Syracuse University Press, 2003.

Anas, Omair et.al. "Fethullah Gülen Movement in South Asia," Indian Council of World Affairs Issue Brief, 5 October 2016.

Aziz, Moh. Ali. Ilmu Dakwah. Jakarta: Kencana, Edisi Revisi Ke-3, 2012.

Barton, Greg. "Preaching by Example and Learning for Life: Understanding the Gülen Hizmet in the Global Context of Religious Philanthropy and Civil Religion," dalam Ihsan Yilmaz (ed.), Muslim World in Transition: Contributions of the Gülen Movement (International Gülen Conference Proceedings), London, UK, 25-27 October 2007. London: Leed Metropolitan University Press, 2007.

Barton, Greg; Weller, Paul; dan Yilmaz, Ihsan (eds.). The Muslim World and Politics in Transition: Creative Contributions of the Gülen Movement. London: Bloomsbury Publishing, 2013.

Bayânûnî (al), Muhammad Abû al-Fath. Al-Madkhal ilâ Tlm al-Da'wah. Beirut: Muassasah al-Risalah, 1993.

Bruinessen, Martin van dan Howell, Julia Day (eds.). Sufism and the Modern' in Islam. New York: I.B. Tauris \& Co. Ltd., 2007.

Chair, Gülen. Mengenal Sosok Fethullah Gülen. Jakarta: Fethullah Gülen Chair UIN Syarif Hidayatullah, 2013.

Conway, Trudy D. Cross-cultural Dialogue on the Virtues: The Contribution of Fethullah Gülen. New York: Springer, 2014.

Djavadi, Abbas. "Turning Away From Gülen's 'Golden Generation'," mmw.rferl.org, August 29, 2016.

Gülen, M. Fethullah. Bangkitnya Spiritualitas Islam, terj. Fuad Saefuddin. Jakarta: Pepublika. 2012.

----. Cahaya al-Qur'ân bagi selurub Makbluk. Jakarta: Republika, 2011.

----. Islam Rahmatan Lil-Alamin, terj. Fauzi A. Bahreisyi. Jakarta: Republika, 2013. 
-----. Membangun Peradaban Kita, terj. Fuad Saefuddin. Jakarta: Republika, 2013.

-----. Pearls of Wisdom, terj. Ali Ünal. New Jersey: The Light Inc., 2005.

----. Prophet Muhammad the Infinite Light, Vol. 1-2. London: Truestar; Istanbul: Kaynak, 1998.

----. Prophet Mubammad: Aspects of His Life, Vol. 1 \& II. Fairfax: the Fountain, 2000.

----. Qadar: Di Tangan Siapakah Takdir atas Diri Kita, terj. Ibnu Ibrahim Ba'adillah. Jakarta: Republika Penerbit, 2011.

----. Reflections on the Qur'an. New Jersey: the Light Inc., 2006.

----. Toward a Global Civilization of Love and Tolerance. New Jersey: The Light Inc. \& Isik Yayinlari, 2004.

----. Towards the Lost Paradise. London: Truestar, 1996.

----. Windows onto the Faith Vol. 10 (The Necessity of Interfaith Dialogue: A Muslim Perspective). New Jersey: the Light Inc., 2005.

----. Dakwab: Jalan Terbaik dalam Berfikir dan Menyikapi Hidup, terj. Ibnu Ibrahim Ba'adillah. Jakarta: Republika Penerbit. 2011.

Hafidhuddin, Didin. Dakwah Aktual. Jakarta: Gema Insani Press, 1998.

Hermansen, Marcia. "The Cultivation of Memory in the Gülen Community," dalam Ihsan Yilmaz (ed.), Muslim World in Transition: Contributions of the Gülen Movement (International Gülen Conference Proceedings), London, UK, 25-27 October 2007. London: Leed Metropolitan University Press, 2007.

Hunt, Robert A. dan Aslandogan, Yuskel A. Muslim Citizens of the Globalized World: Contributions of the Gülen Movement. New Jersey: IID \& The Light Inc., 2007.

Juergensmeyer, Mark. Terror in the Mind of God: The Global Rise of Religious Violence (Comparative Studies in Religion and Society, 13). Berkeley, CA: University of California Press, 2000.

Kalyoncu, Mehmet. A Civilian Response to Ethno-Religious Conflict: The Gülen Movement in Southeast Turkey. Lanham: Tughra Books, 2008.

Kirk, Martha Ann. Hope and Healing: Stories from Northern Iraq Where Persons Inspired by Fethullah Gülen Have Been Serving. Turkey: Gülen Institute, 2011.

Lieberman, Joseph I. dan Collin, Susan M. A Ticking Time Bomb: Counter Terrorism Lesson from the U.S. Government's Failure to Prevent the Fort Hood Attact (A Special Report). Washington D.C.: U.S. Senate Committee on Homeland Security and Governmental Affairs, 2011. 
Liwerant, Judit Bosker. "The Middle East between War and Peace", Journal of American Studies of Turkey, 17, 2003.

Madkhalî (al), Rabî‘ b. Hâdî. Manbaj al-Anbiyâ' fì al-Da'wah ilâ Allâh fî̀ al-Hikmah wa al-'Aql. Kuwait: Dâr al-Salafiyah, 1987.

Mahmûd, 'Alî 'Abd Halîm. Fiqh al-Da'wah al-Fardîyah. Mesir: Dâr alWafâ, 1992.

Mizell, Aland. "The End of Fethullah Gülen's Utopian Society: The Awaited Golden Generation”. kurdistantribune.com, June 27, 2014.

Özdalga, Elisabeth. "Secularizing Trend sin Fethullah Gülen's Movement: Impasse or Opportunity for Further Renewal," Critique (12), 2003.

PASIAD, Mengenal Lebih Dekat PASLAD Indonesia. Jakarta: PASIAD Indonesia. t.th.

Pillar, Paul R. Terrorism and U.S. Foreign Policy with a New Introductory Essay on Counterterrorism since 9/11. Washington D.C.: The Brookings Institution, 2001.

Pratt, Douglas. "Islamic Prospects for Inter-Religious Dialogue: The Contribution of Fethullah Gülen" dalam Ihsan Yilmaz (ed.), Muslim World in Transition: Contributions of the Gülen Movement (International Gülen Conference Proceedings), London, UK, 25-27 October 2007. London: Leed Metropolitan University Press, 2007.

Ramadan, Tariq. Western Muslims and the Future of Islam. Oxford: Oxford University Press Inc., 2005.

Safi, Omid. Progressive Muslims: On Justice, Gender, and Pluralism. Oxford: Oneworld, 2013.

Saritoprak, Zeki dan Griffith, S. "Fethullah Gülen and the 'People of the Book': A Voice from Turkey for Interfaith Dialogue," The Muslim World, Vol. 95, No. 3, July 2005.

Saritoprak, Zeki. "Fethullah Gülen and His Global Contribution to Peace Building" dalam Yilmaz, Ihsan (ed.). Muslim World in Transition: Contributions of the Gülen Movement (International Gülen Conference Proceedings), London, UK, 25-27 October 2007. London: Leed Metropolitan University Press, 2007.

Scheel, Mark. "A Communitarian Imperative: Fethullah Gülen's Model of Modern Turkey," Fountain Magazine, Issue 61/JanuaryFebruary 2008.

Schwartz, Stephen. The Two Faces of Islam: The House Sa'ud from Tradition to Terror. New York: Doubleday, 2002. 
Skubik, Daniel W. "Fethullah Gülen, Islamic Banking and Global Finance," A paper prepared for the Fourth Conference on International Corporate Responsibility, Doha, Qatar, 16-18 November 2008.

Turam, Berna. Between Islam and the State: The Politics of Engagement. Stanford University Press, 2006.

"Turkish School Declared Most Successful in Denmark," bizmetnews.com, 25 August 2015; Source: Today's Zaman, August 12, 2015.

Uygur, Selcuk. "Islamic Puritanism" as a Source of Economic Development: Contributions of the Gülen Movement"; Yilmaz, Ihsan (ed.), Muslim World in Transition: Contributions of the Gülen Movement (International Gülen Conference Proceedings), London, UK, 2527 October 2007. London: Leed Metropolitan University Press, 2007.

Valkenberg, Pim. Renewing Islam by Service: A Christian Wiew of Faetbullah Gülen and Hizmet Movement. Washington, D.C.: The Catholic University of America Press, 2015.

Waardenburg, Jean Jacques. Muslim as Actors; Islamic Meanings and Muslim Interpretations. Berlin: Walter de Gruyter GmbH \& Co., 2007.

Yildirim, Yetkin dan Kirmizialtin, Suphan. 'Fethullah Gülen's Golden Generation: Integration of Muslim Identity with the World through Education," the AMSS 33rd Annual Conference at George Mason University Arlington Campus-Virginia on Sept. 24-6 2004.

Yilmaz, Ihsan (ed.), Muslim World in Transition: Contributions of the Gülen Movement (International Gülen Conference Proceedings), London, United Kingdom, 25-27 October 2007. London: Leed Metropolitan University Press, 2007. 